\title{
被観察場面における語彙流暢課題中の脳活動パターン
}

\author{
○不林佳奈子 ${ }^{1} \cdot$ 松本圭 ${ }^{2} \cdot$ 近江政雄 ${ }^{2}$ \\ ( ${ }^{1}$ 金沢工業大学大学院心理科学研究科 $\cdot{ }^{2}$ 金沢工業大学 $)$ \\ キーワード： 観察者, NIRS, 語彙流暢課題
}

\begin{abstract}
Brain activity during verbal fluency task in the observed scene.
Kanako KIBAYASHI ${ }^{1}$, Kei MATSUMOTO ${ }^{2}$ and Masao $\mathrm{OHMI}^{2}$

( ${ }^{1}$ Graduate School of Psychology, Kanazawa Institute of Technology, ${ }^{2}$ Kanazawa Institute of Technology)
\end{abstract}

Key Words: Observer,NIRS, Verbal fluency task

目 的

近赤外線スペクトロスコピィ（NIRS）を用いて精神疾患と 脳活動の関係を調べる研究が行われている。 Yokoyama et al. （2015）は，社交不安症者を対象に語彙流暢課題中（Verbal fluency task:VFT）の脳活動について研究を行った。彼女らは 「できるだけ多く」単語を報告させるという教示で，非明示 的に否定的な感情（評価不安）の喚起を促した。その結果, VFT 中の前頭前皮質腹外側部（VLPFC）の活動が，健常者に 比べ社交不安症者の方が低いことを明らかにした。健常者で は評価不安を抑制する為に VLPFC の活性化が生じたものの, 社交不安症者はその活動が減弱していたと考察している。し かしVFT 中の不安測定がなされておらず, 不安喚起の操作確 認が不十分である。また不安喚起を行わない統制条件がない ため, 健常者の VLPFC 活動が不安の影響を受けていたことも 確認されていない。本研究は Yokoyama et al.の手続きに以下 の改善を加え, 健常者を対象に実験を行った。それは（1）不 安哃起するための観察者を置くこと，（2）観察者不在の条件 を統制条件とすること，（3）課題中の不安を自己報告質問紙 と生理指標（皮膚コンダクタンス:SC）により多面的に測定す ることの 3 点であった。

\section{方 法}

参加者 学生, 大学院生 10 名（内男性 9 名）を対象とした。 質問紙 新版 STAI を使用した。

装置 NIRS (ETG4000:日立メディコ), SC を測定する Pro Comp Infiniti と SC-FLEX/PRO (Thought Technology Ltd), 教 示呈示用の PC を用いた。

課題 Pre（30 秒）-Task（60 秒）-Post（60 秒）の 3 つの期間 で 1 試行とした。Pre と Post では，参加者に母音（あいうえ お）を繰り返し発語するよう教示した。Task では PC に呈示 された平仮名 1 字から始まる単語を出来るだけ多く発語する よう教示した。20 秒毎に異なる 1 字を呈示した。

手続き 実験手続きの説明後, 国際 10-20 法に基づいて NIRS の光ファイバー端子 $(24 \mathrm{ch})$ を前頭部に, SC 測定器の電極を 人差し指と小指の第 1 関節腹側部に装着した。練習課題の後, 本課題に移行した。本課題は 4 試行で構成されていた。2 試 行は観察者有条件（観察者は机を挟んで参加者の右斜め前に 着席), 残りの 2 試行は観察者無条件であった。各条件ともに 2 試行続けて行われた。条件の実施順序はカウンターバラン スを行った。STAI は各条件の実施前, 中, 後の計 5 回実施し た。本研究は金沢工業大学の倫理委員会の承認を得た上で行 われた（承認番号 0152）。

\section{結 果}

不安喚起の操作確認 状態不安の平均值を従属変数として, 観察者 (有, 無) ×課題（2 試行）の 2 要因分散分析を行った が，有意な主効果及び交互作用はみられなかった。SC は各期
間の最後の 30 秒を分析対象とした。期間毎に求めた電気伝導 度の平均值を従属変数として, 観察者 $($ 有, 無 $) \times$ 期間 $($ Pre,Task, Post) x課題（2 試行）の 3 要因分散分析を行った。その結果, 両観察者条件ともにPostよりもPre と Taskにおいて電気伝導 度が高かった。条件間の主効果は有意傾向であり，観察者有 条件の方が高かった。STAI と SC の結果は不一致だったが, $\mathrm{SC}$ では不安の増加がみられた。

NIRS データの分析 24ch の内ノイズが大きかった $16 \mathrm{ch}$ は除 外し, 残り $8 \mathrm{ch}$ の $\mathrm{Oxy}-\mathrm{Hb}$ 濃度を分析対象とした。 $\mathrm{SC}$ の場合 と同様に, 各期間の平均 $\mathrm{Oxy}-\mathrm{Hb}$ 濃度を $\mathrm{ch}$ 毎に算出した。そ れを従属変数とし, SC と同じ 3 要因分散分析を行った。前頭 中心部にあたる $\operatorname{ch} 10$ の観察者・期間別の平均 $\mathrm{Oxy}-\mathrm{Hb}$ 濃度を 図 1 に示した。ch10 では観察者×期間の交互作用が有意であ った $(F(2,18)=8.08, p<.01)$ 。単純主効果検定の結果，両観 察者条件ともにPreよりも Task, Postにおいて Oxy-Hb 濃度 が高かった（観察者有条件ではいずれも $p<.01$, 無条件ではい ずれも $p<.05)$ 。また条件間では, Pre では差が見られないもの の Task と Post の期間で観察者有条件の方が Oxy-Hb 濃度が高 かった（Task では $p<.01$, Post では $p<.05) 。 \operatorname{ch} 10$ に近接する ch12, ch20 および ch23 においても同様のパターンがみられ た。

\section{考 察}

VFT 中, 前頭中心部の血流増加が見られ，特に被観察場面 でその増加が強くなった。対面対話中に前頭極が活性化する との報告や（Suda et al., 2010），前頭前野が感情抑制と関連し ていることを考慮すると, この前頭中心部の血流増加は, VFT 中に観察者が存在することで生じた感情の調整を反映してい るものと考えられる。

\section{引用文献}

Suda, M., et al. (2010). Frontopolar activation during face-to-face conversation: An in situ study using near-infrared spectroscopy. Neuropsychologia, 48, 441-447.

Yokoyama, C., et al. (2015). Dysfunction of ventrolateral prefrontal cortex underlying social anxiety disorder: A multi-channel NIRS study. NeuroImage:clinical, 8, 455 - 461.

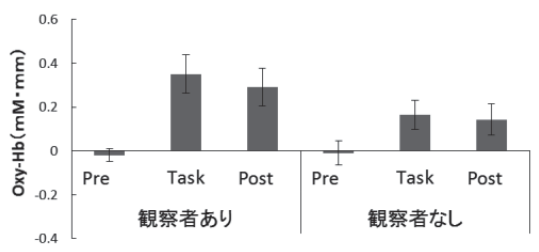

図 $1 \mathrm{ch} 10$ の観察者・期間別の平均 $\mathrm{Oxy}-\mathrm{Hb}$ 濃度 